\title{
DILEMA POLITIK HUKUM \\ PERTAMBANGAN DI INDONESIA SUATU TELAAH \\ ATAS KONSEP PEMBANGUNAN BERKELANJUTAN
}

\author{
Muhammad Junaidi \\ m.junaidi@usm.ac.id \\ Universitas Semarang (USM)
}

\begin{abstract}
Abstrak: Indonesia memliki sumberdaya alam yang sangat mumpuni dibandingkan Negara lain. Pantas saja investasi yang salah satunya pertambangan yang ada di Indonesia menjadi bidikan yang paling menarik investor asing untuk menamkan sahamnya di Indonesia.
\end{abstract}

Persoalan yang mendasar dalam konteks pengelolaan pertambangan tentunya mengacu pada beberapa pasal yang diantaranya UUD 45 pasal 33 ayat yang menyebutkan ; Bumi, air dan kekayaan alam yang terkandung didalamnya dikuasai oleh Negara dan dipergunakan untuk sebesar-besarnya kemakmuran rakyat. Namun dalam praktinya dominasi penguasaan hanya pada segelintir pihak utamanya adalah pihak asing yang sangat dominan dalam mendapatkan untuk dari sumber daya alam yang dimiliki.

Model pengelolaan yang demikian tentunya bertentangan dengan konstitusi kita. Pasal 33 UUD 1945 beserta penjelasannya, melarang adanya penguasaan sumber daya alam ditangan orang ataupun seorang. Dengan kata lain monopoli, tidak dapat dibenarkan namun fakta saat ini berlaku di dalam praktek-praktek usaha, bisnis dan investasi dalam bidang pengelolaan sumber daya alam sedikit banyak bertentangan dengan prinsip pasal 33.

Disinilah kita perlu kembali pada konsep pembangunan berkelanjutan yang merupakan ruh dari pengelolaan sumber daya alam di Indonesia. Konsep pembangunan berkelanjutan bukan hanya menyeimbangkan antara ekonomi, social dan lingkungan dalam upaya menjalankan pembangunan yang ada, akan tetapi juga menitiktekankan pada upaya mengakomodir prinsip keadilan antar generasi.

Kata Kunci: dilema, politik hukum dan pertambangan 
Abstract: Indonesian natural resources possess highly qualified than any other country. No wonder that one of them mining investment in Indonesia became the most attractive shots for menamkan shares foreign investors in Indonesia .

The fundamental issue in the context of mining of course referring to several articles including Article 33, paragraph 45 Constitution which states; Earth, water and natural resources contained therein controlled by the State and used for the prosperity of the people. However, in practice this is only a handful of dominance tenure is the main foreign parties are very dominant in getting to of natural resources owned.

Such management model is certainly contrary to our constitution . Article 33 UUD 1945 with description, prohibit the possession of natural resources in the hands of one or a. In other words monopoly

, but the fact can not be justified at the current prevailing business practices, business and investment in the field of natural resource management a bit much at odds with the principles of Article 33.

This is where we need to go back to the concept of sustainable development which is the spirit of natural resource management in Indonesia. The concept of sustainable development is not only a balance between economic, social and environmental development in an effort to run there, but also emphasize on efforts to accommodate the principle of fairness between generations.

Keywords: dilemma, politics and mining law 


\section{Latar Belakang Masalah}

Manusia dalam memenuhi kebutuhan hidupnya memerlukan sumber daya alam, yang berupa tanah, air, udara dan sumber daya alam yang lain yang termasuk ke dalam sumber daya alam yang terbarukan maupun yang tak terbarukan. Namun demikian harus disadari bahwa sumber daya alam yang kita perlukan mempunyai keterbatasan di dalam banyak hal, yaitu keterbatasan tentang ketersediaan menurut kuantitas dan kualitasnya.

Sumber daya alam tertentu juga mempunyai keterbatasan menurut ruang dan waktu. Oleh sebab itu diperlukan pengelolaan sumber daya alam yang baik dan bijaksana. Antara lingkungan dan manusia saling mempunyai kaitan yang erat. Ada kalanya manusia sangat ditentukan oleh keadaan lingkungan di sekitarnya, sehingga aktivitasnya banyak ditentukan oleh keadaan lingkungan di sekitarnya.

Keberadaan sumber daya alam, air, tanah dan sumber daya yang lain menentukan aktivitas manusia sehari-hari. Kita tidak dapat hidup tanpa udara dan air. Sebaliknya ada pula aktivitas manusia yang sangat mempengaruhi keberadaan sumber daya dan lingkungan di sekitarnya. Kerusakan sumber daya alam banyak ditentukan oleh aktivitas manusia. Banyak contoh kasus-kasus pencemaran dan kerusakan lingkungan yang diakibatkan oleh aktivitas manusia seperti pencemaran udara, pencemaran air, pencemaran tanah serta kerusakan hutan yang kesemuanya tidak terlepas dari aktivitas manusia, yang pada akhirnya akan merugikan manusia itu sendiri.

Dalam konstitusi yaitu UUD 1945 Pasal 33 telah secara jelas bahwa Negara menjadi regulator. Hal Nampak sekali dengan posisi pemerintah sebagai pemegang kendali terhadap kekayaan alam Indonesia yang sangat melimpah. Indonesia 
memiliki sumber daya alam yang luar biasa, maka sudah sangar rasional sekali menunjukkan bahwa pertambangan di Indonesia menjadi bidikan perusahaan dalam negeri maupun utamanya perusahaan luar negeri. Data statistik pengelolaan pertambangan di Indonesia sebagai berikut :

Table 1.1

Produksi Minyak Bumi dan Gas Alam, 1996-2011

\begin{tabular}{|c|c|c|c|}
\hline \multirow[t]{2}{*}{ Tahun } & Minyak Mentah & Kondensat & Gas Alam \\
\hline & (barel) & (barel) & (MMscf) \\
\hline 1996 & $485,573.80$ & $63,074.50$ & $3,164,016.20$ \\
\hline 1997 & $484,340.60$ & $59,412.00$ & $3,166,034.90$ \\
\hline 1998 & $480,109.70$ & $54,782.30$ & $2,978,851.90$ \\
\hline 1999 & $440,461.60$ & $54,181.40$ & $3,068,349.10$ \\
\hline 2000 & $434,368.80$ & $50,024.50$ & $2,845,532.90$ \\
\hline 2001 & $432,588.00$ & $47,528.10$ & $3,765,828.50$ \\
\hline 2002 & $351,949.60$ & $45,358.90$ & $2,289,373.90$ \\
\hline 2003 & $339,100.00$ & $44,600.00$ & $2,142,605.00$ \\
\hline 2004 & $354,351.90$ & $50,641.00$ & $3,026,069.30$ \\
\hline 2005 & $341,202.60$ & $46,450.90$ & $2,985,341.00$ \\
\hline 2006 & $313,037.20$ & $44,440.20$ & $2,948,021.60$ \\
\hline 2007 & $305,137.40$ & $43,210.60$ & $2,805,540.30$ \\
\hline 2008 & $314,221.70$ & $44,497.00$ & $2,790,988.00$ \\
\hline 2009 & $301,663.40$ & $44,649.60$ & $2,887,892.20$ \\
\hline
\end{tabular}


Jurnal IQTISAD 4 (2) (2017)

p-ISSN: 2303-3223 e-ISSN: 2621-640X

iqtisad@unwahas.ac.id

Dilema Politik Hukum ....

\begin{tabular}{|l|l|l|l|}
2010 & $300,923.30$ & $43,964.70$ & $3,407,592.30$ \\
\hline 2011 & $289,899.00$ & $39,350.30$ & $3,256,378.90$ \\
\hline
\end{tabular}

Sumber : Kementrian Energi dan Sumber Daya Mineral (ESDM)

Table 1.3

Produksi Barang Tambang Mineral, 1996-2011

\begin{tabular}{|c|c|c|c|c|c|}
\hline Tahun & $\begin{array}{l}\text { Batu } \\
\text { Bara } \\
\text { (ton) }\end{array}$ & $\begin{array}{c}\text { Bauksit } \\
\text { (ton) }\end{array}$ & $\begin{array}{l}\text { Nikel } \\
\text { (ton) }\end{array}$ & $\begin{array}{c}\text { Emas } \\
(\mathrm{kg})\end{array}$ & $\begin{array}{r}\text { Perak } \\
(\mathrm{kg})\end{array}$ \\
\hline 1996 & $\begin{array}{l}50332 \\
047\end{array}$ & 841976 & 3426867 & 83564 & $\begin{array}{l}255 \\
404\end{array}$ \\
\hline 1997 & \begin{tabular}{|l|}
55982 \\
040
\end{tabular} & 808749 & 2829936 & 86928 & $\begin{array}{l}249 \\
392\end{array}$ \\
\hline 1998 & $\begin{array}{l}58504 \\
660\end{array}$ & 1055647 & 2736640 & 123862 & $\begin{array}{l}383 \\
191\end{array}$ \\
\hline 1999 & $\begin{array}{l}62108 \\
239\end{array}$ & 1116323 & 2798449 & 127768 & $\begin{array}{l}361 \\
377\end{array}$ \\
\hline 2000 & $\begin{array}{l}67105 \\
675\end{array}$ & 1150776 & 2434585 & 109612 & $\begin{array}{l}310 \\
430\end{array}$ \\
\hline 2001 & $\begin{array}{l}71072 \\
961\end{array}$ & 1237006 & 2473825 & 148528 & $\begin{array}{l}333 \\
561\end{array}$ \\
\hline 2002 & $\begin{array}{l}105539 \\
301\end{array}$ & 1283485 & 2120582 & 140246 & $\begin{array}{l}281 \\
903\end{array}$ \\
\hline 2003 & $\begin{array}{l}113525 \\
813\end{array}$ & 1262705 & 2499728 & 138475 & $\begin{array}{l}272 \\
050\end{array}$ \\
\hline 2004 & $\begin{array}{l}128479 \\
707\end{array}$ & 1331519 & 2105957 & 86855 & $\begin{array}{l}255 \\
053\end{array}$ \\
\hline
\end{tabular}




\begin{tabular}{|c|c|c|c|c|c|}
\hline 2005 & $\begin{array}{l}149665 \\
233\end{array}$ & 1441899 & 3790896 & 142894 & $\begin{array}{l}326 \\
993\end{array}$ \\
\hline 2006 & $\begin{array}{l}162294 \\
657\end{array}$ & 2117630 & 3869883 & 138992 & $\begin{array}{l}270 \\
624\end{array}$ \\
\hline 2007 & $\begin{array}{l}188663 \\
068\end{array}$ & 1251147 & 7112870 & 117854 & $\begin{array}{l}268 \\
967\end{array}$ \\
\hline 2008 & $\begin{array}{l}178930 \\
188\end{array}$ & 1152322 & 6571764 & 64390 & $\begin{array}{l}226 \\
051\end{array}$ \\
\hline 2009 & $\begin{array}{l}228806 \\
887\end{array}$ & 935211 & 5819565 & 140488 & $\begin{array}{l}359 \\
451\end{array}$ \\
\hline 2010 & $\begin{array}{l}325325 \\
793\end{array}$ & 2200000 & 9475362 & 119726 & $\begin{array}{l}335 \\
040\end{array}$ \\
\hline 2011 & $\begin{array}{l}415765 \\
068\end{array}$ & 24714940 & $\begin{array}{l}12482 \\
829\end{array}$ & 68220 & $\begin{array}{l}227 \\
173\end{array}$ \\
\hline
\end{tabular}

Sumber : Kementrian Energi dan Sumber Daya Mineral (ESDM)

Jumlah asset alam Indonesia yang sangat luar biasa tersebut, secara jelas telah dilindungi dalam konstitusi kita yaitu dalam UUD 1945. Terjemahan dari Pasal 33 UUD 1945 hasil amandemen terakhir tertuang dalam beberapa Undang-undang di bawahnya yang diantaranya dalam Undang-Undang Republik Indonesia Nomor 4 Tahun 2009 Tentang Pertambangan Mineral Dan Batubara.

Namun dalam praktiknya pengelolaan pertambangan kita masih didominasi asing dan cenderung dimanfaatkan untuk kepentingan bangsa di luar kita. Beberapa dasar yang dapat penulis gunakan diantaranya gambar di bawah ini: 


\section{Gambar 1.1}

Jumlah Izin Usaha Pertambangan Di Indonesia Selama 2011

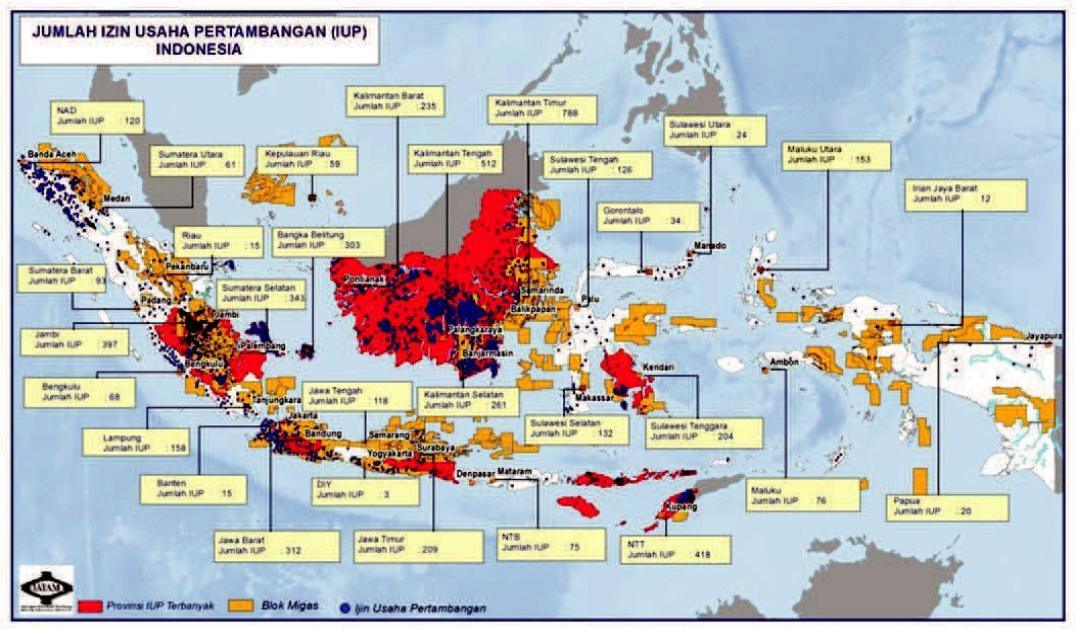

Sumber : Jaringan Tambang (Jatam)

Dipihak lain pertambangan yang demikian signifikan tersebut telah menonjol didominasi oleh investor asing. Berdasarkan data di bawah ini menunjukkan sebaran investasi asing dalam mengelola pertambangan Migas dan Gas Metana Batubara di Indonesia yaitu sebagai berikut :

\section{Gambar 1.2}

Peta Kepemilikan Pengelolaan Migas dan Gas Metana Batubara

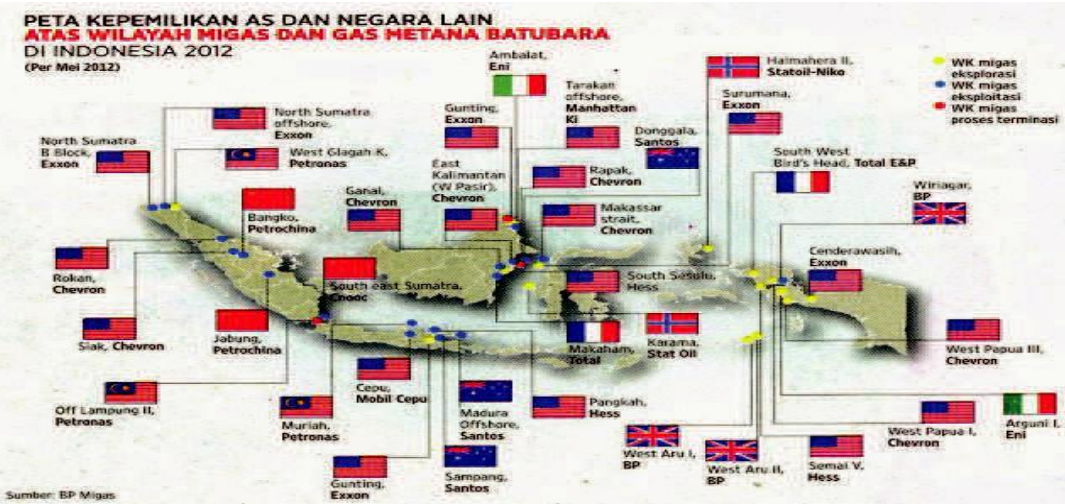

Sumber : Bp Migas yang sekarang menjadi SKK Migas kementrian Esdm

Frans Magni Suseno menyatakan bahwa dalam kapitalisme, Sumber Daya Alam (SDA) hanya dijadikan sarana belaka untuk 
memenuhi kebutuhan manusia. Lebih lanjut dikatakan "bahwa alam bernilai pada dirinya sendiri dan oleh karenanya perlu dipelihara tidak termasuk dalam wawasan kapitalisme". Dari pernyataan Magnis Suseno tersebut dapat dijelaskan bahwa kapitalisme mengkonsepsikan lingkungan dalam pandangan antroposentrik. Otto Soemarwoto menyebutkan, antrosoposentrisme ialah pandangan manusia terhadap lingkungan hidup yang menempati kepentingan manusia di pusatnya. $^{12}$

Pandangan yang praktis demikian, kiranya telah menjadi sebuah karakter dalam pengelolaan pertambangan di Negara kita saat ini. Cara berpikir yang praktis dan dengan menempatkan logika ekonomis, menjadikan sudut pandanga dalam melakukan pengelolaan pertambangan hanya bisa dinikmati secara tidak penuh pada masa saat ini, terlebih lagi pada masa yang akan datang tentunya.

\section{Konsep Pembangunan Berkelanjutan Dalam Ranah Hukum}

Konsep pembangunan berkelanjutan sebenarnya peneliti masukkan mengingat jika terjadi dilema atas keseimbangan kepentingan ekonomi, ekosistem dan sosial, maka yang sepatumya menjadi prioritas utamanya ketimbang memilih salah satu antara kepentingan ekonomi, ekosistem atau sosial adalah memprioritaskan pembangunan masa yang akan datang di samping juga melakukan pembangunan saat ini. Konsepsi ini sangat layak untuk digunakan sebagai penengah atas persoalan dilema kesimbangan ekonomi, sosial, dan ekosistem atas dampak emisi karbon akibat meningkatnya penggunaan kendaraan bermotor.

1 Adji Samekto, 2008, Kapitalisme, Moderenisasi Dan Kerusakan Lingkungan, Genta Press, Yogyakarta, hlm 23 
Berkaiatan dengan konsep pembangunan yang berkesinambungan (sustainable development) telah menghendaki agar setiap usaha pembangunan prasarana dan sarana fisik yang dilakukan tetap memelihara kondisi lingkungan. Salah satu aspek lingkungan adalah udara, di mana di dalamnya udara terkandung sejumlah oksigen yang merupakan komponen esensial bagi kehidupan, baik manusia maupun makhluk hidup lainnya.

Salah satu teori sebagai bentuk menyeimbangkan antara persoalan kepentingan ekonomi, ekologi dan sosial adalah teori pembangunan berkelanjutan. Pembangunan berkelanjutan atau sustainable development adalah proses pembangunan yang berprinsip pada pemenuhan kebutuhan sekarang tanpa mengorbankan pemenuhan kebutuhan generasi masa depan.

Pada prinsipnya intensitas pembangunan dewasa ini kerapkali mengesampingkan aspek kelestarian dalam pelaksanaannya. Kerusakan lingkungan akibat pembangunan infrastruktur, pembalakan, penambangan, pembukaan lahan pertanian dan perkebunan bukan hanya menjadi masalah bagi Indonesia, tetapi juga menjadi isu internasional saat ini. Atas dasar kondisi demikian maka muncullah apa yang disebut pembangunan berkelanjutan.

Oleh World Commision on enironmental and Development (WCED) pembangunan berkelanjutan diartikan sebagai "pembangunan yang memenuhi kebutuhan-kebutuhan dari generasi sekarang, tanpa membahayakan kesanggupan generasigenerai mendatang untuk memenuhi kebutuhan-kebutuhan mereka sendiri". 2 Dalam kaitannya engan pembangunan berkelanjutan, terdapat dua kaidah yang harus diperhatikan dalam pengelolaan sumber daya alam dan lingkungan, yaitu ${ }^{3}$ :

2 K. bartens, 2000, Pengantar Etika Bisnis, Penerbit Kanisius, Jogyakarta, hlm.320-321

${ }^{3}$ Pearce, D.W. and Turner, R.K, 1990, Economics of Natural Resources and the Environment. Harvester Wheatsheaf, London, hlm 36 
1. Untuk sumber daya alam yang terbarukan (renewable resources): Laju pemanenan harus lebih kecil atau sama dengan laju regenerasi (produksi lestari).

2. Untuk masalah lingkungan: Laju pembuangan (limbah) harus lebih kecil atau setara dengan kapasitas asimilasi lingkungan. Aspek operasional dari konsep keberlanjutan ini dapat dipahami

lebih jauh dengan adanya lima alternatif pengertian sebagaimana yang diuraikan Perman et al., ${ }^{4}$ sebagai berikut:

1. Suatu kondisi dikatakan berkelanjutan (sustainable) jika utilitas yang diperoleh masyarakat tidak berkurang sepanjang waktu dan konsumsi tidak menurun sepanjang waktu (nondeclining consumption).

2. Keberlanjutan adalah kondisi dimana sumber daya alam dikelola sedemikian rupa untuk memelihara kesempatan produksi di masa mendatang.

3. Keberlanjutan adalah kondisi dimana sumber daya alam (natural capital stock) tidak berkurang sepanjang waktu (non-declining).

4. Keberlanjutan adalah kondisi dimana sumber daya alam dikelola untuk mempertahankan produksi jasa sumber daya alam.

5. Keberlanjutan adalah kondisi dimana kondisi minimum keseimbangan dan daya tahan (resilience) ekosistem terpenuhi.

Selain definisi operasional di atas, Haris ${ }^{5}$ melihat bahwa konsep keberlanjutan dapat diperinci menjadi tiga aspek pemahaman, yaitu:

1. Keberlanjutan ekonomi, yang diartikan sebagai pembangunan yang mampu menghasilkan barang dan jasa secara kontinyu untuk memelihara keberlanjutan pemerintahan dan menghindari terjadinya

${ }^{4}$ Fauzi, A, 2004, Ekonomi Sumber Daya Alam dan Lingkungan, PT. Gramedia Pustaka Utama, Jakarta, hlm 48

${ }^{5}$ Ibid., 23 
ketidakseimbangan sektoral yang dapat merusak produksi pertanian dan industri.

2. Keberlanjutan lingkungan: Sistem yang berkelanjutan secara lingkungan harus mampu memelihara sumber daya yang stabil, menghindari eksploitasi sumber daya alam dan fungsi penyerapan lingkungan. Konsep ini juga menyangkut pemeliharaan keanekaragaman hayati, stabilitas ruang udara, dan fungis ekosistem lainnya yang tidak termasuk kategori sumber-sumber ekonomi.

3. Keberlanjutan sosial: Keberlanjutan secara sosial diartikan sebagai sistem yang mampu mencapai kesetaraan, menyediakan layanan sosial termasuk kesehatan, pendidikan, gender, dan akuntabilitas politik.

Menurut Munasinghe, ${ }^{6}$ pembangunan berkelanjutan mempunyai tiga tujuan utama, yaitu: tujuan ekonomi (economic objective), tujuan ekologi (ecological objective) dan tujuan sosial (sosial objective). Tujuan ekonomi terkait dengan masalah efisiensi (efficiency) dan pertumbuhan (growth); tujuan ekologi terkait dengan masalah konservasi sumber daya alam (natural resources conservation); dan tujuan sosial terkait dengan masalah pengurangan kemiskinan (poverty) dan pemerataan (equity). Sehingga, dengan demikian, tujuan pembangunan berkelanjutan pada dasarnya terletak pada adanya harmonisasi antara tujuan ekonomi, tujuan ekologi dan tujuan sosial.

Dalam deklarasi Stookholm dan deklarasi Rio Dejeniore yang dimotori oleh Perserikatan Bangsa-Bangsa (PBB) menyepakati 5 (lima) prinsip pembangunan berkelanjutan yang bukan hanya mementingkan kepentingan kebutuhan pada saat ini namun juga pada masa yang akan datang.

6 Munasinghe, M. 1993. Environmental Economics and Sustainable Development, !e World Bank, Washington, D.C. hlm 56 
Kelima pinsip dalam pembangunan berkelanjutan tersebut adalah sebagai berikut: ${ }^{7}$

1. Prinsip keadilan antar generasi.

Prinsip ini mengandung makna bahwa setiap generasi umat manusia di dunia ini memiliki hak untuk menerima dan menempati bumi bukan dalam kondisi yang buruk akibat perbuatan generasi sebelumnya.

2. Prinsip keadilan dalam satu generasi

Prinsip keadilan dalam satu generasi (intra generation equity) merupakan prinsip yang berbicara tentang keadilan di dalam sebuah generasi umat manusia, dimana beban dari permasalahan lingkungan harus dipikul bersama oleh masyarakat dalam suatu generasi.

3. Prinsip pencegahan dini

Prinsip pencegahan dini (precautionary principle) mengandung suatu pengertian bahwa apabila terdapat ancaman yang berarti, atau adanya ancaman kerusakan lingkungan yang tidak dapat dipulihkan, ketiadaan temuan atau pembuktian ilmiah yang kongklusif dan pasti, tidak dapat dijadikan alasan untuk menunda upaya-upaya untuk mencegah terjadinya kerusakan lingkungan.

4. Prinsip perlindungan keragaman hayati

Perlindungan keragaman hayati merupakan prasarat dari berhasil tidaknya pelaksanaan prinsip keadilan antar generasi (inter generational equity principle). Perlindungan keragaman hayati juga terkait dengan masalah pencegahan sebab mencegah kepunahan jenis dari keragaman hayati diperlukan demi pencegahan dini.

5. Internalisasi biaya lingkungan

Untuk mendukung tercapainya tujuan yang ada tersebut sangatlah dibutuhkan perangkat hukum sebagai pendukung.

\footnotetext{
${ }^{7}$ FX. Adji Samekto, hlm 102-103
} 
Satjipto Rahardjo menegaskan bahwa hukum adalah suatu institusi yang bertujuan mengantarkan manusia kepada kehidupan yang adil, sejahtera dan membuat manusia bahagia. ${ }^{8}$

Berangkat dari prinsip tersebut, Undang-Undang Dasar Negara Republik Indonesia Tahun 1945 yang salah satunya terdapat dalam Bab XIV tentang Perekonomian Nasional dan Kesejahteraan Sosial Pasal 33 ayat 3 menyebutkan bahwa "Bumi dan air dan kekayaan alam yang terkandung di dalamnya dikuasai oleh Negara dan dipergunakan untuk sebesar-besarnya kemakmuran rakyat".

Hal ini dapat disimpulkan bahwa kekayaan alam yang ada di negara Indonesia wajib untuk dilindungi dan dimanfaatkan sebaik mungkin untuk kepentingan masa depan penerus bangsa. Selain itu segala macam bentuk penyimpangan merupakan suatu hal yang wajib diluruskan dengan perangkat hukum yang ada baik dengan teguran atau sanksi.

Selain Undang-Undang Dasar Negara Republik Indonesia Tahun 1945, di Indonesia upaya perlindungan terhadap kerusakan lingkungan yang disebabkan oleh gas buang kendaraan bermotor juga telah digagas secara lebih rinci dalam Undang-Undang Nomor 32 tahun 2009 tentang Lingkungan Hidup.

Undang-Undang Nomor 32 tahun 2009 tentang masalah Lingkungan hidup menjabarkan di antaranya dalam Bab X Hak, Kewajiban, dan Larangan Bagian Kesatu Hak Pasal 65 yaitu :

(1) Setiap orang berhak atas lingkungan hidup yang baik dan sehat sebagai bagian dari hak asasi manusia.

(2) Setiap orang berhak mendapatkan pendidikan lingkungan hid-up, akses infonnasi, akses partisipasi, dan akses keadilan dalam memenuhi hak atas lingkungan hidup yang baik dan sehat

\footnotetext{
${ }^{8}$ Satjipto Rahardjo, 2009, Hukum Progresif Sebuah Sinfesa Hukum Indonesia, Genta Publishing, Yogyakarta, hlm 2
} 
(3) Setiap orang berhak mengajukan usul dan/atau keberatan terha-dap rencana usaha dan/atau kegiatan yang diperkirakan dapat menimbulkan dampak terhadap lingkungan hidup.

(4) Setiap orang berhak untuk berperan dalam perlindungan dan pengelolaan lingkungan hidup sesuai dengan peraturan perundangundangan.

(5) Setiap orang berhak melakukan pengaduan akibat dugaan pencemaran dan/atau perusakan lingkungan hidup.

(6) Ketentuan lebih lanjut mengenai tata cara pengaduan sebagaimana dimaksud pada ayat (5) diatur dengan Peraturan Menteri. Tanggung jawab terhadap pengelolaan lingkungan sangatlah mutlak di wajibkan bagi semua kalangan, baik pemerintah pusat, korporasi, maupun masyarakat pada umumnya. Tanggung jawab ini telah diakomodir juga dalam Undang-Undang Nomor 32 tahun 2009 tentang Pengelolaan dan Perlindungan Lingkungan Hidup pada Bab IX Tugas Dan Wewenang Pemerintah Dan Pemerintah Daerah Pasal 63 yaitu:

(1) Dalam perlindungan dan pengelolaan lingkungan hidup, Pemerintah bertugas dan berwenang:

a. Menetapkan kebijakan nasional;

b. Menetapkan norma, standar, prosedur, dan kriteria;

c. Menetapkan dan melaksanakan kebijakan mengenai RPPLH nasional;

d. Menetapkan dan melaksanakan kebijakan mengenai KLHS;

e. Menetapkan dan melaksanakan kebijakan mengenai amdal dan UKL-UPL;

f. Menyelenggarakan inventarisasi sumber daya alam nasional dan emisi gas rumah kaca;

g. Mengembangkan standar kerja sama;

h. Mengoordinasikan dan melaksanakan pengendalian pencemaran dan/atau kerusakan lingkungan hidup;

i. Menetapkan dan melaksanakan kebijakan mengenai sumber daya alam hayati dan nonhayati, keanekaragaman 
hayati, sumber daya genetik, dan keamanan hayati produk rekayasa genetik;

j. Menetapkan dan melaksanakan kebijakan mengenai pengendalian dampak perubahan iklim dan perlindungan lapisan ozon;

k. Menetapkan dan melaksanakan kebijakan mengenai B3, limbah, serta limbahB3;

1. Menetapkan dan melaksanakan kebijakan mengenai perlindungan lingkungan laut;

m. Menetapkan dan melaksanakan kebijakan mengenai pencemaran dan/atau kerusakan lingkungan hidup lintas batas negara;

n. Melakukan pembinaan dan pengawasan terhadap pelaksanaan kebijakan nasional, peraturan daerah, dan peraturan kepala daerah;

o. Melakukan pembinaan dan pengawasan ketaatan penanggung jawab usaha dan/atau kegiatan terhadap ketentuan perizinan lingkungan dan peraturan perundangundangan;

p. Mengembangkan dan menerapkan instrumen lingkungan hidup;

q. Mengoordinasikan dan memfasilitasi kerja sama dan penyelesaian perselisihan antardaerah serta penyelesaian sengketa;

r. Mengembangkan dan melaksanakan kebijakan pengelolaan pengaduan masyarakat;

s. Menetapkan standar pelayanan minimal;

t. Menetapkan kebijakan mengenai tata cara pengakuan keberadaan masyarakat hukum adat, kearifan lokal, dan hak masyarakat hukum adat yang terkait dengan perlindungan dan pengelolaan lingkungan hidup;

u. Mengelola informasi lingkungan hidup nasional; 
v. Mengoordinasikan, mengembangkan, dan mensosialisasikan pemanfaatan teknologi ramah lingkungan hidup;

w. Memberikan pendidikan, pelatihan, pembinaan, dan penghargaan;

x. Mengembangkan sarana dan standar laboratorium lingkungan hidup;

y. Menerbitkan izin lingkungan;

z. Menetapkan wilayah ekoregion; dan Melakukan penegakan hukum lingkungan hidup.

(2) Dalam perlindungan dan pengelolaan lingkungan hidup, pemerintah provinsi bertugas dan berwenang:

a. Menetapkan kebijakan tingkat provinsi;

b. Menetapkan dan melaksanakan KLHS tingkat provinsi;

c. Menetapkan dan melaksanakan kebijakan mengenai RPPLH provinsi;

d. Menetapkan dan melaksanakan kebijakan mengenai amdal dan UKL-UPL;

e. Menyelenggarakan inventarisasi sumber daya alam dan emisi gas rumah kaca pada tingkat provinsi;

f. Mengembangkan dan melaksanakan kerja sama dan kemitraan;

g. Mengoordinasikan dan melaksanakan pengendalian pencemaran dan/atau kerusakan lingkungan hidup lintas Kabupaten/kota;

h. Melakukan pembinaan dan pengawasan terhadap pelaksanaan kebijakan, peraturan daerah, dan peraturan kepala daerah Kabupaten/kota;

i. Melakukan pembinaan dan pengawasan ketaatan penanggung jawab usaha dan/atau kegiatan terhadap ketentuan perizinan lingkungan dan peraturan perundangundangan di bidang perlindungan dan pengelolaan Lingkungan hidup;

j. Mengembangkan dan menerapkan instrumen lingkungan hidup; 
k. Mengoordinasikan dan memfasilitasi kerja sama dan penyelesaian persebsihan antarKabupaten/antarkota serta penyelesaian sengketa;

1. Melakukan pembinaan, bantuan teknis, dan pengawasan kepada Kabupaten/kota di bidang program dan kegiatan;

m. Melaksanakan standar pelayanan minimal;

n. Menetapkan kebijakan mengenai tata cara pengakuan keberadaan masyarakat hukum adat, kearifan lokal, dan hak masyarakat hukum adat yang terkait dengan perlindungan dan pengelolaan lingkungan hidup pada tingkat provinsi;

o. Mengelola informasi lingkungan hidup tingkat provinsi;

p. Mengembangkan dan menyosialisasikan pemanfaatan teknologi ramah lingkungan hidup;

q. Memberikan pendidikan, pelatihan, pembinaan, dan penghargaan;

r. Menerbitkan izin lingkungan pada tingkat provinsi; dan

s. Melakukan penegakan hukum lingkungan hidup pada tingkat provinsi.

(3) Dalam perlindungan dan pengelolaan lingkungan hidup, pemerintah Kabupaten/kota bertugas dan berwenang:

a. Menetapkan kebijakan tingkat Kabupaten/kota;

b. Menetapkan dan melaksanakan KLHS tingkat Kabupaten/ kota;

c. Menetapkan dan melaksanakan kebijakan mengenai RPPLH Kabupaten/ kota;

d. Menetapkan dan melaksanakan kebijakan mengenai amdal dan UKL-UPL;

e. Menyelenggarakan inventarisasi sumber daya alam dan emisi gas rumah kaca pada tingkat Kabupaten/kota;

f. Mengembangkan dan melaksanakan kerja sama dan kemitraan;

g. Mengembangkan dan menerapkan instramen lingkungan hidup;

h. Memfasilitasi penyelesaian sengketa; 
i. Melakukan pembinaan dan pengawasan ketaatan penanggung jawab usaha dan/atau kegiatan terhadap ketentuan perizinan lingkungan dan peraturan perundangundangan;

j. Melaksanakan standar pelayanan minimal;

k. Melaksanakan kebijakan mengenai tata cara pengakuan keberadaan masyarakat hukum adat, kearifan lokal, dan hak masyarakat hukum adat yang terkait dengan perlindungan dan pengelolaan lingkungan hidup pada tingkat Kabupaten/ kota;

1. Mengelola infonnasi lingkungan hidup tingkat Kabupaten/ kota;

m. Mengembangkan dan melaksanakan kebijakan sistem informasi lingkungan hidup tingkat Kabupaten/kota;

\section{Rekonstruksi Pengelolaan Pertambangan}

Dalam hal ini peran pemerintah untuk membentuk suatau tatanan yang sesuai dengan karakter masyarakat sangat penting sekali. Ada dua bentuk perbuatan atau tindakan pemerintah, yakni perbuatan berdasarkan hukum (rechhandeling) dan tindakan berdasarkan fakta/ nyata atau bukan berdasarkan hukum (feitelijkhandeling). Perbuatan pemerintah berdasarkan hukum dapat dimaknai sebagai perbuatan-perbuatan yang berdasarkan sifatnya dapat menimbulkan akibat hukum tertentu untuk menciptakan hak dan kewajiban. Perbuatan ini lahir sebagai konsekuensi logis dalam kedudukannya pemerinah sebagai subjek hukum, sehingga perbuatan hukum yang dilakukan menimbulkan akibat hukum, sedangkan perbuatan pemerintah berdasarkan fakta/nyata (bukan hukum) adalah perbuatanyang tidak langsung berhubungan dengan kewenangannya dan tidak berakibat hukum. Menurut Kuntjoro Purbopranoto, perbuatan berdasarkan fakta ini tidak relevan dan tidak mempunyai hubungan langsung dengan kewenangannya. Contoh : upacara membuka jembatan, pembuka jalan raya dan 
lain-lain yang biasanya dilakukan oleh seorang penguasa pemerintah. ${ }^{9}$

Dalam proses pembuatan aturan perizinan pertambangan, perbuatan yang dilakukan oleh pemerintah juga termasuk perbuatan berdasarkan hukum (rechhandeling). Perizinan sendiri berasal dari kata "izin" dan menurut kamus hukum "izin" berarti pernyataan mengabulkan (tidak melarang dan sebagainya); persetujuan membolehkan. Sedangkan "perizinan" berarti hal memberi izin. ${ }^{10}$

Penulis dalam memfokuskan masalah perizinan dalam kaitannya politik hukum pengelolaan pertambangan dengan melihat pemerintah terlalu leluasa dalam memberikan izin pengelolaan pertambangan yang selama ini diberikan utamanya kepada investor asing. Keberpihakan pengeloaan oleh negara sendiri yang tentunya dengan mengedepankan aspek pembangunan tidak lagi menjadi prioritas utama.

Beberapa kasus telah menunjukkan bagaimana sistem pengelolaan investor asing yang bukan hanya merugikan rakyat akan tetapi sistem pengelolaan pertambangan mereka telah memberikan dampak negatif bagi rakyat. Kita ambil contoh saja pada pengelolaan pertambangan di newmont, dalam situs satuharapan.com, Jaringan Advokasi Tambang (Jatam) bersama Kepala Desa Tongo Sejorong, Hasanuddin, dan Kepala Desa Sekongkang Bawah, Rahmat Hidayat mewakili masyarakat desa mereka menggelar konferensi pers di kantor Jatam, pada Senin ini (26/8), di Jakarta. Dalam situs tersebut kemudian diberitahukan bahwa kehadiran kedua kepala desa dari kecamatan Sekongkang, Kabupaten Sumbawa Barat, Provinsi

${ }^{9}$ Kuntjoro Purbopranoto, 1975, Beberapa Catatan Hukum Tata Negara dan Peradilan Administrasi Negara, Alumni, Bandung, hlm. 44.

10 Pusat pembinaan dan pengembangan Bahasa, Departemen Pendidikan dan Kebudayaan, 1995, Kamus Besar Bahasa Indonesia, Balai Pustaka, Jakarta, hlm. 391. 
Nusa Tenggara Barat (NTB) ini, menuntut kewajiban dan pertanggungjawaban kepada pihak perusahaan pertambangan berkaitan dengan dampak kerusakan lingkungan hidup yang berasal dari PT. Newmont Nusa Tenggara (PT. NNT).

Problem ini sepatutnya jika ditinjau dari pemberian izin pengelolaan pertambangan, pemerintah tidak tegas. Sepatutnya pemerintah harus membuat regulasi yang secara tegas mencabut izin pengelolaan pertambangan bagi perusahaan pertambangan yang secara teknis pengelolaan pertambangan secara sadar melakukan pengrusakan lingkungan secara tidak langsung.

Namun yang menjadi permasalahan selanjutnya pemerintah bahkan melakukan perlindungan-perlindungan dari perilaku yang menyimpang tersebut yaitu dengan membiarkannya terjadi berlarut-larut. Dampak yang signifikan selanjutnya adalah dirasakan oleh masyarakat tentunya.

Peran pemerintah tentunya menjadikan hukum menjadi tegas dan mampu menyelesaikan persoalan pertambangan yang selama ini penuh dengan ketidakpastian. Hukum adalah kontrol sosial dari pemerintah (law is governmental social control), sebagai aturan dan proses sosial yang mencoba mendorong perilaku, baik yang berguna atau mencegah perilaku yang buruk. ${ }^{11}$ Di sisi lain kontrol sosial adalah jaringan atau aturan dan proses yang menyeluruh yang membawa akibat hukum terhadap perilaku tertentu, misalnya aturan umum perbuatan melawan hukum. ${ }^{12}$ Tidak ada cara lain untuk memahami sistem hukum selain melihat perilaku hukum yang dipengaruhi oleh aturan keputusan pemerintah atau undang-undang yang

${ }^{11}$ Donald Black, 1976, “Behavior of Law”, New York, San Fransisco, London: Academic Press, hlm. 2.

${ }^{12}$ Lawrence Friedman,1984, “American Law”, London: W.W. Norton \& Company, hlm. 3. 
dikeluarkan oleh pejabat yang berwenang. Jika seseorang berperilaku secara khusus adalah karena diperintahkan hukum atau karena tindakan pemerintah atau pejabat lainnya atau dalam sistem hukum.

Hukum akan menjadi berarti apabila perilaku manusia dipengaruhi oleh hukum dan apabila masyarakat menggunakan hukum menuruti perilakunya, sedangkan di lain pihak efektivitas hukum berkaitan erat dengan masalah kepatuhan hukum sebagai norma. Hal ini berbeda dengan kebijakan dasar yang relatif netral dan bergantung pada nilai universal dari tujuan dan alasan pembentukan undang-undang.

Penegakan hukum pada prinsipnya harus dapat memberi manfaat atau berdaya guna (utility) bagi masyarakat, namun di samping itu masyarakat juga mengharapkan adanya penegakan hukum untuk mencapai suatu keadilan. Kendatipun demikian tidak dapat kita pungkiri, bahwa apa yang dianggap berguna (secara sosiologis) belum tentu adil, begitu juga sebaliknya apa yang dirasakan adil (secara filosopis), belum tentu berguna bagi masyarakat.

Dalam kondisi yang demikian ini, masyarakat hanya menginginkan adanya suatu kepastian hukum, yaitu adanya suatu peraturan yang dapat mengisi kekosongan hukum tanpa menghiraukan apakah hukum itu adil atau tidak. Kenyataan sosial seperti ini memaksa pemerintah untuk segera membuat peraturan secara praktis dan pragmatis, mendahulukan bidangbidang yang paling mendesak sesuai dengan tuntutan masyarakat tanpa perkiraan strategis, sehingga melahirkan peraturan-peraturan yang bersifat tambal sulam yang daya lakunya tidak bertahan lama. Akibatnya kurang menjamin kepastian hukum dan rasa keadilan dalam masyarakat. 
Gagasan-gagasan dalam pengelolaan pertambangan tentunya tidak bisa lepas dari kaidah-kaidah hukum yang mempunyai kepastian dan hukum yang diperankan mampu merespon terhadap persoalan pertmabangan yang ada dengan segera. Problem yang dihadapi dalam pembuatan regulasi dan implementasinya terhadap pengelolaan pertambangan adalah terdapat konfigurasi politik yang melahirkan produk hukum. Mahfud membedakan secara diametral corak atau konfigurasi politik menjadi dua kutub yang berbeda yaitu konfigurasi politik demokratis yang diartikan sebagai susunan sistem politik yang membuka kesempatan (peluang) bagi partisipasi masyarakat secara penuh untuk ikut aktif menentukan kebijaksanaan umum. Sementara konfigurasi politik yang kedua adalah konfigurasi politik otoriter diartikan sebagai susunan sistem politik yang lebih memungkinkan negara berperan sangat aktif serta mengambil hampir seluruh inisiatif dalam pembuatan kebijakan negara.

Kecenderuangan yang ada dalam politik hukum pengelolan pertambangan adalah pada posisi konfiguarasi lebih yang lebih politik otoriter diartikan sebagai susunan sistem politik yang lebih memungkinkan negara berperan sangat aktif serta mengambil hampir seluruh inisiatif dalam pembuatan kebijakan Negara. Keterlibatan masyarakat sangat minim dalam hal ini. Indicator model konfigurasi demikian adalah pemerintah kurang merespon secara cepat setiap permasalahan yang ada dalam pertambangan seperti pencemaran limbah yang terjadi di Newmont dan bagi hasil pertambangan yang sangat minim mensejahterakan masyarakat.

kemudian harus menjadi solusi alternatif yaitu sebaiknya mekanisme dan prosedur untuk menentukan prioritas revisi atau pembentukan undang-undang baru, masyarakat harus 
mengetahui sedini mungkin dan tidak memancing adanya resistensi dari masyarakat, maka setidak-tidaknya dilakukan dua macam pendekatan yaitu pendekatan sistem dan pendekatan kultural politis.

Melalui pendekatan sistem prioritas revisi atau pembentukan undang-undang baru, harus dilihat secara konstekstual dan konseptual yang bertalian erat dengan dimensi-dimensi geopolitik, ekopolitik, demopolitik, sosiopolitik dan kratopolitik. Dengan kata lain politik hukum tidak berdiri sendiri, lepas dari dimensi politik lainnya, apalagi jika hukum diharapkan mampu berperan sebagai sarana rekayasa sosial. Kepicikan pandangan yang hanya melihat hukum sebagai alat pengatur dan penertib saja, tanpa menyadari keserasian hubungannya dengan dimensidimensi lain, akan melahirkan produk dan konsep yang kaku tanpa cakrawala wawasan dan pandangan sistemik yang lebih luas dalam menerjemahkan perasaan keadilan hukum masyarakat. $^{13}$

Substansi undang-undang sebaiknya disusun secara taat asas, harmoni dan sinkron dengan nilai-nilai yang terkandung dalam Pancasila dan Undang-undang Dasar 1945. Untuk itu harus dilakukan dengan mengabstraksikan nilai-nilai yang terkandung dalam Pancasila dan Undang-undang Dasar 1945 kemudian menderivasi, yakni menurunkan sejumlah asas-asas untuk dijadikan landasan pembentukan undang-undang. Semua peraturan-peraturan hukum yang dikeluarkan secara sektoral oleh departemen-departemen yang bersangkutan harus serasi dan sinkron dengan ketentuan undang-undang. Perlu kita

${ }^{13}$ Selanjutnya dijelaskan bahwa faktor utama: (1) kesatuan wilayah sebagai subsistimnya adalah geopolitik; (2) kesatuan masyarakat sebagai subsistemnya adalah sosiopolitik; (3) kesatuan cita, perjuangan dan tujuan sebagai subsistimnya adalah ekopolitik; (4) kesatuan sumber moral sebagai subsistimnya adalah demopolitik; dan kesatuan sistim hukum dan sistim pemerintahan sebagai subsistimnya adalah kratopolitik. M. Solly Lubis, 1989, "Serba-serbi Politik dan Hukum", Bandung: Mandar Maju, hlm. 48 dan 94-96. 
maklumi bahwa banyak peraturan undang-undang sering tidak berpijak pada dasar moral yang dikukuhi rakyat, bahkan sering bertentangan.

\section{Kesimpulan}

Pengelolaan pertambangan di indonesia mengalami dilemma yang serius selama ini. Problem yang dihadapi bukan pada masalah ketidakmampuan pemerintah dalam mengelola, akan tetapi kecenderungan terjadinya konfigurasi politik yang melahirkan produk hukum yang pada posisi ini lebih cenderung melahirkan produk-produk kebijakan yang represid dan menguntungkan pihak tertentu.

Indicator yang dapat membuktikan terjadinya dilemma tersebut adalah adanya pembuangan limbah yang terus-menerus oleh perusahaan pertambangan seperti Newmont yang tidak ditanggapi secara serius oleh diberikan kepada masyarakat terutama masyarakat yang berada pada zona terdekat dengan pertambangan sangatlah minim. Hal ini kemudian memungkinkan konflik implementasi keberlanjutan pembangunan yang meliputi prinsip keadilan antar generasi, prinsip keadilan dalam satu generasi, prinsip pencegahan dini, Prinsip perlindungan keragaman hayati dan Internalisasi biaya lingkungan.

Kecenderungan yang harus diciptakan baik dalam melakukan pembuatan regulasi pertambangan dan mengimplementasikannya adalah bagaimana menciptakannya sesuai system prioritas. Sebagai pendukung dari system yang diciptakan kemudian, maka susunan sistem politik yang dihadirkan harus membuka kesempatan (peluang) selebarlebarnya bagi partisipasi masyarakat secara penuh untuk ikut aktif menentukan kebijaksanaan umum.[] 


\section{Daftar Pustaka}

Adji Samekto, 2008, Kapitalisme, Moderenisasi Dan Kerusakan Lingkungan, Genta Press, Yogyakarta

Donald Black, 1976, "Behavior of Law", New York, San Fransisco, London: Academic Press

Fauzi, A, 2004, Ekonomi Sumber Daya Alam dan Lingkungan, PT. Gramedia Pustaka Utama, Jakarta

K. bartens, 2000, Pengantar Etika Bisnis, Penerbit Kanisius, Jogyakarta

Kuntjoro Purbopranoto, 1975, Beberapa Catatan Hukum Tata Negara dan Peradilan Administrasi Negara, Alumni, Bandung

Lawrence Friedman, 1984, "American Law", London, W.W. Norton \& Company

M. Solly Lubis, 1989, "Serba-serbi Politik dan Hukum”, Bandung:

\section{Mandar Maju}

Munasinghe, M. 1993. Environmental Economics and Sustainable Development, !e World Bank, Washington, D.C

Pearce, D.W. and Turner, R.K, 1990, Economics of Natural Resources and the Environment. Harvester Wheatsheaf, London

Pusat pembinaan dan pengembangan Bahasa, Departemen Pendidikan dan Kebudayaan, 1995, Kamus Besar Bahasa Indonesia, Balai Pustaka, Jakarta

Satjipto Rahardjo, 2009, Hukum Progresif Sebuah Sinfesa Hukum Indonesia, Genta Publishing, Yogyakarta 